BMJ. Vol 6 No 2, 2019: 163-172

ISSN : 2615-7047

DOI: https://doi.org/10.36376/bmj.v6i2

Disubmit 7 Agustus 2019

Diterima 30 Desember 2019

\title{
HUBUNGAN FAKTOR INTERNAL MAHASISWA DENGAN PRESTASI BELAJAR
}

\section{“RELATIONSHIP BETWEEN INTERNAL STUDENT FACTORS AND STUDENT ACHIEVEMENTS"}

\author{
Nikodemus Sili Beda ${ }^{1}$, Dianri Nistia Salutondok ${ }^{2}$, Dianri Nistia Salutondok ${ }^{3}$ \\ Sekolah Tinggi Ilmu Kesehatan Stella Maris Makassar \\ (Stella Maris Institute of Health Sciences Makassar)
}

\begin{abstract}
ABSTRAK
Keberhasilan mahasiswa dapat dilihat dari prestasi belajar yang ditempuh selama beberapa waktu. Faktor internal berperan penting dalam pencapaian prestasi belajar yang baik. Berdasarkan data yang didapatkan, dapat dilihat pencapaian nilai $>2,75$ dan $<2,75$ sangat berbeda tipis. Jika tidak segera dicegah maka kemungkinan besar jumlah prestasi belajar yang baik akan menurun. Tujuan penelitian ini yaitu untuk mengetahui hubungan faktor internal mahasiswa dengan prestasi belajar. Penelitian ini merupakan jenis penelitian observasional analyticdengan pendekatan Cross Sectional study. Populasi penelitian ini adalah semua mahasiswa program DIII tingkat II dengan jumlah sampel sebanyak 66 responden yang diambil dengan menggunakan teknik probability sampling melalui pendekatan systematic random sampling. Hasil penelitian menggunakan uji Chi Square (pearson Chi-Sqaure) dengan nilai $X_{\text {hitung }}^{2}=45,438$, nilai $X_{\text {tabel }}^{2}=7,815$ dan juga diperoleh nilai $\mathrm{p}=0.000$ dimana nilai $\alpha=0.05$. hal ini menunjukkan bahwa $\mathrm{x}^{2}{ }_{\text {hitung }}>\mathrm{x}^{2}$ tabel dan nilai $\mathrm{p}$ $<\alpha$, maka Ho ditolak dan Ha diterima. Dengan demikian, dapat ditarik kesimpulan bahwa terdapat hubungan antara faktor internal mahasiswa dengan prestasi belajar. Oleh karena itu disarankan kepada mahasiswaagar lebih kritis dalam memilih dan mengambil keputusan yang berkaitan dengan faktor internalnya sehingga tidak berpengaruh kepada prestasi belajarnya.
\end{abstract}

Kata Kunci : Fakor Internal Mahasiswa, Prestasi Belajar

ABSTRACT

Student success can be seen from the learning achievements taken for some time. Internal factors play an important role in achieving good learning achievement. Based on the data obtained, it can be seen the achievement score $>2.75$ and $<2.75$ are not very different. If it is not immediately prevented then it is likely that the number of good learning achievements will decrease. The purpose of this study is to determine the relationship between internal factors of students and learning achievement. This research is an analytic observational research with cross sectional study approach. The population of this study was all students of the II level program with a total sample of 66 respondents taken using probability sampling techniques through a systematic random sampling approach. The results of the study used the Chi Square test (Pearson Chi-Sqaure) with a calculated $X 2$ value $=45.438$, $a$ value of X2table $=7.815$ and also a $p$ value $=0.000$ 
BMJ. Vol 6 No 2, 2019: 163-172

DOI: https://doi.org/10.36376/bmj.v6i2

where a value of $\alpha=0.05$. this shows that $x 2$ count $>x 2$ table and $p$ value $<\alpha$, then Ho is rejected and Ha is accepted. Thus, it can be concluded that there is a relationship between internal factors of students with learning achievement. Therefore it is suggested to students to be more critical in choosing and making decisions related to internal factors so that it does not affect their learning achievement.

Keywords: Student Internal Factors, Learning Achievement

\begin{tabular}{ll}
\hline Alamat Korespondensi & $\begin{array}{l}\text { Jl. Maipa No.19, Losari, Kec. Ujung Pandang, Kota Makassar, } \\
\text { Sulawesi Selatan. }\end{array}$ \\
Email & nikodemusriantoby@yahoo.co.id
\end{tabular}

\section{PENDAHULUAN}

Salah satu sarana untuk mencapai tujuan pendidikan nasional adalah meningkatkan mutu pendidikan disetiap jenjang pendidikan yang ada. Meningkatkan mutu pendidikan pada dasarnya adalah meningkatkan prestasi belajar siswa. Arah dan tujuan mutu pendidikan adalah untuk menghasilkan lulusan yang berkualitas, yakni yang tidak hanya bisa menyesuaikan diri dengan keadaan masyarakat, namun bisa melestarikan dan mengembangkan masyarakat. Kemampuan dan kualitas lulusan tersebut pertama-tama ditunjukkan dengan prestasi belajar yang dicapai mahasiswa dengan usaha untuk meningkatkan mutu pendidikan pada dasarnya adalah meningkatkan prestasi belajar mahasiswa (Wiyono Budi, 2003).

Negara Indonesia sebagai salah satu negara di Asia Tenggara yang dalam masa berkembang sedang menghadapi permasalahan yang serius dalam dunia pendidikan. Hal ini mengakibatkan Sumber Daya Manusia (SDM) Indonesia kalah bersaing pada tataran wilayah Asia. Berdasarkan tinjauan literature, menurut survei Political and Economic Risk Consultant (PERC), kualitas pendidikan di Indonesia berada pada urutan ke-12 dari 12 negara di Asia. Posisi Indonesia berada di bawah Vietnam. Data yang dilaporkan The Wold Economic Forum Swedia (2000), Indonesia memiliki daya saing yang rendah, yaitu menduduki urutan ke-37 dari 57 negara yang di survei di dunia. Dan masih survei dari lembaga yang sama, Indonesia hanya berpredikat sebagai follower bukan sebagai pemimpin teknologi dari 53 negara di dunia (Handayani Sri, 2008).

Kualitas pendidikan di Indonesia saat ini sangat memprihatinkan. Ini dibuktikan antara lain dengan data UNESCO (2000) tentang peringkat Indeks Pengembangan Manusia (Human Development Index), yaitu komposisi dari peringkat pencapaian pendidikan, kesehatan, dan penghasilan per kepala yang menunjukkan bahwa indeks pengembangan manusia Indonesia makin menurun. Diantara 174 negara di dunia, Indonesia menempati urutan ke-102 (1996), ke-99 (1997), ke-105 (1998), dan ke-109 (1999), (Ganis 2010).

Prestasi belajar mahasiswa di perguruan tinggi merupakan salah satu tolak ukur kualitas Sumber Daya Manusia Indonesia dan alat untuk mengukur keberhasilan perguruan tinggi dalam penyelenggaraan sistem pendidikan. Perguruan tinggi sebagai basis perbaikan dan peningkatan kualitas pendidikan di 
Indonesia memiliki peran strategis untuk melakukan berbagai langkah-langkah kongkrit dalam upaya menciptakan Sumber Daya Manusia Indonesia yang berkualitas dan memiliki daya saing yang tinggi. Jika Indonesia dari tahun ke tahun hanya menjadi follower saja, maka Negara kita akan mengalami perlambatan dalam mengikuti era globalisasi masa kini. Ini semua dimulai dari setiap diri bangsa terutama bagi pelajar sebagai bibit-bibit bangsa dimasa mendatang, terlabih khusus bagi mahasiswa yang sudah lebih dalam mengikuti ilmu pengetahuan, memiliki banyak pengalaman, dan tahu dalam mempertimbangkan suatu keputusan. Faktor internal merupakan hal penting yang harus diketahui kemudian dipahami oleh setiap individu. Ini dikarenakan faktor-faktor ini lahir dari dalam diri individu sendiri. Jika masalah dari dalam dirinya sendiri tidak diketahui dan dipahami, maka akan mengganggu bahkan merusak apa yang sedang dan akan dialaminya.

Berdasarkan studi pendahuluan yang dilakukan pada bulan Juli 2009/2010 mengenai "Hubungan Motivasi Belajar Dengan Indeks Prestasi Akademik Mahasiswa Program Studi DIII Keperawatan di STIKES Wira Husada Yogyakarta", terdapat 2 mahasiswa tingkat I dan 4 mahasiswa tingkat II yang tidak boleh mengikuti ujian akhir semester karena kehadiran kurang dari 75\%. Sedang terdapat 3 mahasiswa tingkat III mangkir (bolos) praktik klinik keperawatan di rumah sakit dan yang lebih memprihatinkan ada 2 mahasiswa yang hampir di tiap ruang selama periode praktik klinik (16 minggu dengan 16 ruang rawat) selalu mangkir satu, dua atau tiga hari. Berdasarkan indek prestasi akademik yang diperoleh, untuk mahasiswa tingkat II ada 7 orang yang kurang dari 2,00 dan 10 orang masih ada mata kuliah yang belum lulus, sedang pada mahasiswa tingkat III ada 2 orang yang kurang dari 2,00 dan 5 orang masih ada mata kuliah yang belum lulus (Jurnal, M.Handari 2009/2010). Dari penelitian ini yang hanya meneliti tentang "Hubungan Motivasi Belajar Dengan Indeks Prestasi Akademik Mahasiswa" masih banyak terdapat mahasiswa yang bermasalah baik dengan kepribadiannya maupun dengan prestasi yang dicapai.

Keberhasilan siswa dalam belajar dapat dilihat dari hasil belajar siswa tersebut. Hasil belajar siswa yang tinggi akan memberikan dorongan dan semangat siswa meningkatkan minat belajar terhadap mata pelajaran, karena minat merupakan sesuatu yang sangat penting bagi seorang dalam melakukan sesuatu kegiatan. Jika seseorang mempelajari sesuatu dengan penuh keyakinan maka diharapkan hasilnya akan baik, namun apabila seseorang tidak memiliki keyakinan untuk mempelajari sesuatu maka jangan diharapkan bahwa seseorang dapat berhasil dengan baik dalam mempelajari hal tersebut. Penelitian-penelitian sebelumnya hanya meneliti mengenai motivasi atau minat sebagai factor internal yang mempengaruhi prestasi belajar dan belum ada penelitian mengenai faktor internal lain dari prestasi belajar secara bersamaan seperti Fisiologis dan Psikologis yang terdiri dari intelegensi, bakat, minat, motivasi, dan sikap.

\section{METODE PENELITIAN}

Jenis penelitian ini merupakan penelitian observasional analitic yang mencari hubungan antar variabel (Setiadi, 2012:68) yang tergolong dalam jenis penelitan Non-Eksperimen . Rancangan yang digunakan dalam penelitian ini pendekatan Cross Sectional study yaitu rancangan penelitian yang digunakan untuk mengukur variabel independen dan dependen pada waktu yang bersamaan 
DOI: https://doi.org/10.36376/bmj.v6i2

dengan maksud untuk melihat hubungan faktor internal dengan prestasi mahasiswa (A.Aziz Alimul H,2007).

Populasi dalam penelitian ini menggunakan populasi terjangkau yaitu populasi yang memenuhi kriteria penelitian dan biasanya dapat dijangkau oleh peneliti. Populasi dalam penelitian ini berjumlah 133 mahasiswa. Sampel Pengambilan sampel dalam penelitian ini dilakukan dengan menggunakan teknik probablility sampling dengan pendekatan systematic random sampling yaitu pengambilan sampel dilakukan secara acak. Cara ini dipakai jika anggota polulasi dianggap homogen. Tujuan yang ingin dicapai dengan cara adalah agar dapat melakukan pengamatan dan pemeriksaan pada sebagian anggota populasi dimana dapat ditarik kesimpulan secara umum (Setiadi, 2012), dan mengacu pada teknik sampling maka besar sample pada penelitian ini adalah 66 yang diperoleh dari jumlah populasi 133 mahasiswa yang diberikan nomor urut pada setiap kuesioner kemudian yang digunakan adalah setiap nomor genap atau teknik pengambilan data ini adalah dengan nomor kuesioner kelipatan dua.

\section{HASIL}

\section{HASIL DAN PEMBAHASAN}

Pengambilan sampel berdasarkan penentuan besar sampel dari jumlah populasi 133 adalah 66 mahasiswa. Teknik pengambilan sampel yang digunakan adalah probability sampling dengan pendekatan systematic random sampling. Pengumpulan data dengan menggunakan kuisioner dan dokumentasi sebagai alat ukur dan pengolahan data dengan menggunakan computer program SPSS for windows versi 20.

Berdasarkan penelitian yang telah dilakukan pada Mahasiswa, diperoleh data dimana jumlah responden terbanyak berada pada umur 19 tahun yaitu $28(42,42 \%)$ responden dan jumlah responden terkecil terdapat pada umur 18, 23, dan 26 tahun yaitu $2(3,03 \%)$ responden.

Distribusi Frekuensi Responden Berdasarkan Umur Mahasiswa

\begin{tabular}{|c|c|c|}
\hline Umur & Frekuensi & Persentasi (\%) \\
\hline $\mathbf{1 8}$ & 2 & 3,03 \\
\hline $\mathbf{1 9}$ & 28 & 42,42 \\
\hline $\mathbf{2 0}$ & 26 & 39,39 \\
\hline $\mathbf{2 1}$ & 6 & 9,1 \\
$\mathbf{2 3}$ & 2 & 3,03 \\
\hline $\mathbf{2 6}$ & 2 & 3,03 \\
\hline Total & 66 & 100 \\
\hline
\end{tabular}

Sumber: Data Primer 
DOI: https://doi.org/10.36376/bmj.v6i2

Hasil penelitian yang telah dilakukan menunjukan bahwa responden berjenis perempuan berjumlah $43(65,1 \%)$ responden dan berjenis kelamin laki-laki berjumlah $23(34,9 \%)$ responden.

Distribusi Frekuensi Responden Berdasarkan Jenis Kelamin Mahasiswa

\begin{tabular}{ccc}
\hline Jenis Kelamin & Frekuensi & Persentasi (\%) \\
\hline Perempuan & 43 & 65,1 \\
Laki-laki & 23 & 34,9 \\
Total & 66 & 100 \\
\hline
\end{tabular}

Sumber: Data Primer

Untuk Analisa Univariat didapatkan data bahwa responden yang menyatakan faktor internal baik yaitu $44(66,7 \%)$ responden sedangkan faktor internal kurang baik yaitu $22(33,3 \%)$ responden

Distribusi Frekuensi Responden Berdasarkan Faktor Internal

\begin{tabular}{ccc}
\hline Faktor Internal & Frekuensi & Persentasi (\%) \\
\hline Baik & 44 & 66,7 \\
Kurang Baik & 22 & 33,3 \\
Total & 66 & 100
\end{tabular}

Kategori prestasi belajar pada mahasiswa menunjukkan bahwa pada dengan pujian memuaskan yaitu $8(12,1 \%)$ responden, yang berada pada kategori sangat memuaskan yaitu $25(37,9 \%)$ responden, sebagian besar berada pada kategori memuaskan yaitu $17(25,8 \%)$ responden, dan pada kategori kurang memuaskan yaitu $16(24,2 \%)$ responden.

Distribusi Frekuensi Responden Berdasarkan Prestasi Belajar

\begin{tabular}{ccc}
\hline IPK & Frekuensi & Persentasi (\%) \\
\hline Dengan Pujian & 8 & 12,1 \\
Sangat Memuaskan & 25 & 37,9 \\
Memuaskan & 17 & 25,8 \\
Kurang Memuaskan & 16 & 24,2 \\
Total & 66 & 100 \\
\hline
\end{tabular}

Berdasarkan hasil analisa antara hubungan faktor internal dengan prestasi didapatkan faktor internal mahasiswa dengan kategorik baik dan prestasi belajar kategorik dengan pujian sebanyak $8(12,1 \%)$ responden, prestasi belajar dengan kategorik sangat memuaskan sebanyak $23(34,9 \%)$ responden, prestasi belajar 
BMJ. Vol 6 No 2, 2019: 163-172

DOI: https://doi.org/10.36376/bmj.v6i2

dengan kategorik memuaskan sebanyak $13(19,7 \%)$ responden, dan prestasi belajar dengan kategori kurang memuaskan sebanyak $0(0 \%)$ responden

Analisa Hubungan Faktor Internal Mahasiswa Dengan Prestasi Belajar

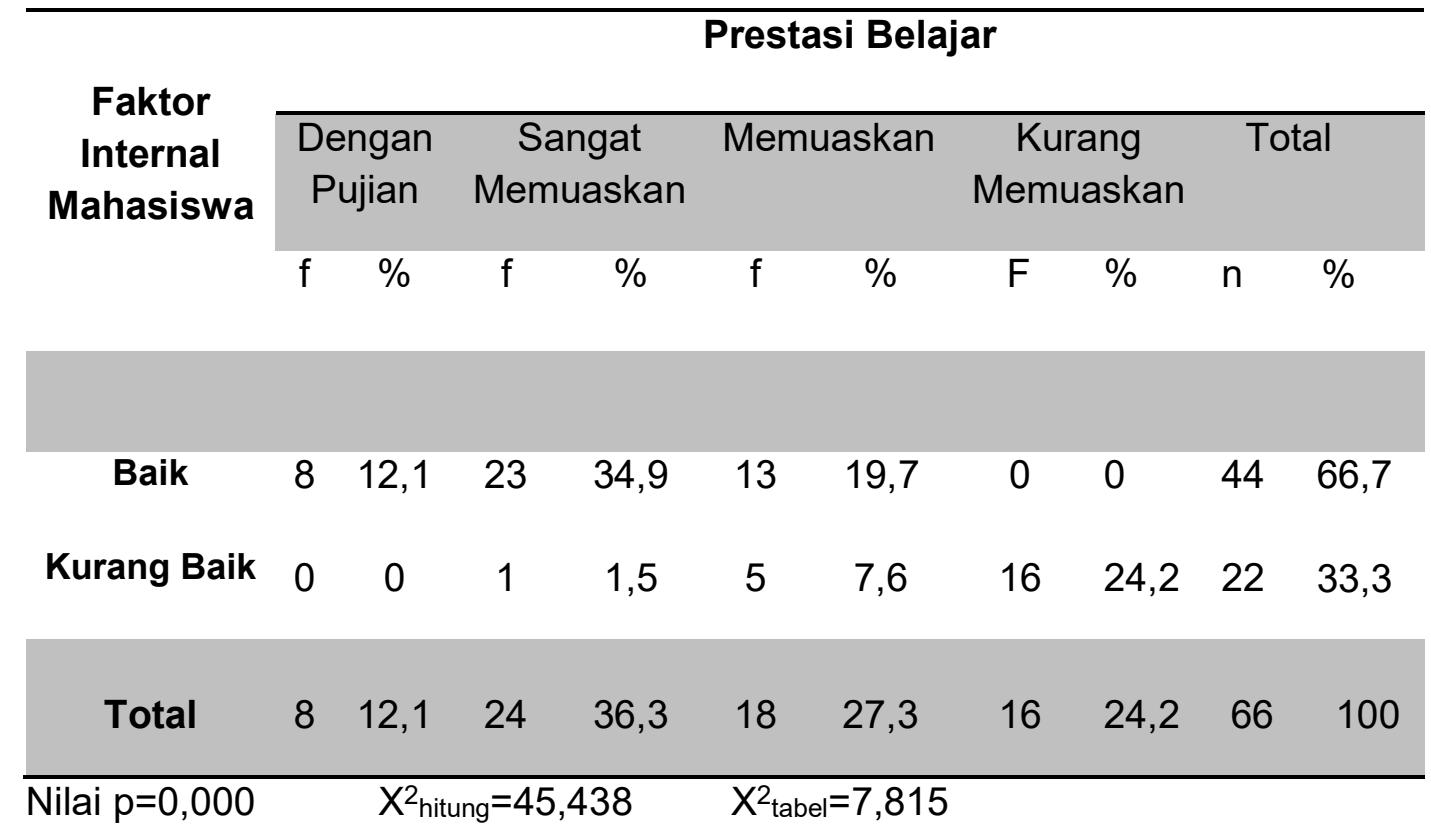

\section{PEMBAHASAN}

Dalam meneliti hubungan faktor internal mahasiswa dengan prestasi belajar diperoleh data $8(12,1 \%)$ responden menyatakan faktor internal dengan kategori baik dan prestasi belajar berada pada kategori dengan pujian. Peneliti berasumsi bahwa intelegensi merupakan bagian dari faktor internal yang berada pada point utama dari faktor psikologis karena dengan intelegensi yang baik maka seorang akan lebih mudah beradaptasi terhadap apapun yang dihadapi, baik dalam berpikir maupun bersikap. Semakin baik tingkat intelegensi seseorang, maka akan semakin pula hasil yang akan diterimanya. Ini dikarenakan individu tersebut bisa menguasai, mengontrol, dan meneliti setiap sesuatu yang baru dihadapinya baik itu mengenai materi baru dari dosen, lingkungan sekitar (keluarga, teman-teman), maupun keadaan dirinya yang berada pada situasi yang tidak biasanya (sakit, kurang bersemangat).

Hubungan faktor internal mahasiswa dengan prestasi belajar diperoleh data $23(34,9 \%)$ responden menyatakan faktor internal dengan kategori baik dan prestasi belajar sangat memuaskan. Peneliti berasumsi bahwa berdasarkan hasil penelitian, sebagian besar mahasiswa memiliki motivasi yang kuat sebagai landasan untuk mempertahankan bahkan meningkatkan prestasi belajarnya agar tujuannya dapat diraih sesuai dengan harapannya. Contohnya menanamkan minat dan dorongan pada diri sendiri terhadap semua yang sudah dipikirkan untuk masa depannya dengan prestasi belajar yang harus dicapai. Kemudian hal lainnya individu mendapatkan motivasi dari orang tua berupa pujian, atau bahkan sebaliknya dengan melihat kondisi keluarga sehingga individu berniat untuk merubah menjadi lebih 
DOI: https://doi.org/10.36376/bmj.v6i2

baik dan membuktikan kepada orang tua atau orang lain dengan prestasi belajar yang dicapai.

Hubungan faktor internal mahasiswa dengan prestasi belajar diperoleh data $13(19,7 \%)$ responden menyatakan faktor internal dengan kategori baik dan prestasi belajar memuaskan. Peneliti berasumsi bahwa untuk mendapatkan hasil yang diinginkan dibutuhkan juga bakat sebagai dasar dari setiap awal langkah yang akan ditempuh. Seseorang akan lebih mudah menjalani aktivitasnya jika ia memiliki suatu pegangan yang disadari bahkan dikuasainya. Semakin seseorang mendalami bakat apa yang dimilikinya, maka hasil yang akan diperolehnya pun akan semakin memuaskan. Contohnya, berada dalam dunia keperawatan berarti kita terpanggil untuk merawat orang yang membutuhkan uluran tangan kita untuk menjaga, memperhatikan mereka hingga kembali pulih. Dasar inilah yang perlu diketahui oleh setiap mahasiswa keperawatan karena tidak semua orang bisa memiliki bakat untuk merawat orang sakit. Bahkan tidak banyak mahasiswa keperawatan yang melenceng dari profesinya sebagai mahasiswa keperawatan sebelumnya. Setiap orang yang dapat bertahan dan mengembangkan potensi yang di dalam dirinya, maka akan berdampak sangat baik jika hal itu dilakukannya juga dengan serius.

Hubungan faktor internal mahasiswa dengan prestasi belajar diperoleh data $1(1,5 \%)$ responden menyatakan faktor internal kurang baik dengan prestasi belajar sangat memuaskan. Asumsi peneliti bertentangan dengan teori di atas karena meskipun kesehatan merupakan modal utama seseorang berdiri tegak sebelum melangkah, bukan berarti orang yang memiliki gangguan kesehatan tidak memiliki modal utama. Ada beberapa hal yang mempengaruhi seseorang yang meskipun memiliki gangguan kesehatan akan tetapi masih memiliki kemauan yang kuat untuk memperoleh prestasi belajar yang baik. Contohnya, dorongan dan motivasi dari orang-orang tercinta berupa memberikan hadiah kepada mahasiswa jika dapat meraih hasil yang memuaskan. Hal ini diperkuat dengan pendapat M. Dalyono 2005 yang mengemukakan bahwa secara psikologi motivasi merupakan usaha yang dapat menyebabkan seseorang atau kelompok tertentu, tergerak hatinya untuk melakukan sesuatu karena ingin mendapatkan kepuasan dengan apa yang dilakukannya (mencapai tujuan yang diinginkankannya).

Hubungan faktor internal mahasiswa dengan prestasi belajar dengan kategori memuaskan diperoleh $5(7,6 \%)$ responden menyatakan faktor internal kurang baik dengan prestasi belajar memuaskan. Menurut Nini Subini (2012) yaitu daya ingat yang rendah sangat mempengaruhi proses dan hasil belajar. namun asumsi peneliti bertentangan dengan pendapat tersebut. Hal ini diperkuat dengan Pendapat lain disampaikan oleh M.Dalyono (2005) yakni salah satu yang termasuk dalam motivasi intrinsik untuk belajar yaitu adanya sifat positif dan kreatif yang ada pada manusia dan keinginan untuk maju. peneliti berasumsi bahwa seseorang harus menyadari apa yang sedang terjadi pada dirinya (apa saja termasuk proses belajarnya) dan tentu saja memikirkan solusi apa yang harus ia pakai agar masalah itu dapat teratasi paling tidak meminimalkannya. Berbicara mengenai daya ingat semua akan menuju pada lansia karena hal itu merupakan proses yang normal. Usia bagi mahasiswa adalah dewasa muda yang rata-rata berkisar 18-26 tahun yang menurut pandangan orang banyak bahwa daya ingat tentunya masih sangat baik. Tetapi tidak terpikirkan bahwa mahasiswa yang memiliki prestasi belajar kategori sesuai standar bahkan dibawah standar tidak menutup kemungkinan memiliki keluhan yang sama yakni daya ingat yang rendah mengenai mata kuliah yang 
didukung juga dengan gaya maupun pribadi dosen yang bersangkutan. Melihat hal ini, ada beberapa cara yang digunakan untuk mempertahankan atau meningkatkan hasil belajar yakni belajar dengan meminta bantuan kepada teman yang dianggap mampu untuk memberikan penjelasan yang lebih mudah dicerna, membuat konsep untuk bahan ujian, dan meminta jawaban dari teman saat ujian berlangsung. Beberapa cara ini merupakan jalan untuk mempertahankan atau meningkatkan prestasi belajarnya sesuai dengan kapasitas factor internal yang dialaminya entah cara yang dipakai adalah cara yang baik maupun cara yang tidak baik. Jika cara yang dipakainya adalah cara yang tidak baik tentunya ada factor lain (factor eksternal) yang mempengaruhinya sehingga individu menentukan pilihannya.

Hubungan faktor internal mahasiswa dengan prestasi belajar diperoleh 16 $(24,2 \%)$ responden menyatakan faktor internal dengan kategori kurang baik dengan prestasi belajar kurang memuaskan. Djaali (2012) mengemukakan bahwa sikap (faktor internal) merupakan salah satu tipe karakteristik afektif yang sangat menentukan keberhasilan seseorang dalam proses pembelajaran. Sejalan dengan pendapat diatas, maka peneliti berasumsi bahwa jika tipe karakteristik afektif dari individu mahasiswa kurang baik maka akan berdampak pula pada prestasi belajar. Seperti contoh, mahasiswa malas tahu terhadap perkuliahan sehingga berujung pada prestasi belajar yang kurang memuaskan. Dalam hal ini bukan hanya menitikberatkan pada sikap tetapi semua aspek faktor internal yang bersifat negative maka akan menghasilkan prestasi belajar yang kurang.

Dan hal tersebut, didukung juga oleh hasil uji statistik dengan menggunakan uji Pearson Chi-Square dan diperoleh nilai $\mathrm{X}^{2}{ }_{\text {hitung }}=45,438$ dimana nilai $\mathrm{X}_{\text {tabel }}{ }^{2}=7,815$. Hal ini menunjukkan bahwa $\mathrm{X}^{2}$ hitung $>\mathrm{X}_{\text {tabel, }}^{2}$ maka hipotesis nol (Ho) ditolak dan hipotesis alternatif (Ha) diterima, dengan demikian menyatakan bahwa ada hubungan faktor internal mahasiswa dengan prestasi belajar program DIII keperawatan Sekolah Tinggi Ilmu Kesehatan Stella Maris Makassar. Hal ini sejalan dengan pendapat yang dikemukakan oleh Admin (2010) yaitu prestasi belajar merupakan hasil dari suatu proses yang di dalamnya terdapat sejumlah factor yang saling mempengaruhi, tinggi rendahnya prestasi siswa tergantung pada factor internal dan eksternal. Agustin (2011) juga mengemukakan bahwa prestasi belajar siswa sifatnya relative, artinya berubah setiap saat. Tinggi rendahnya prestasi belajar siswa didukung oleh factor internal dan eksternal. Sejalan dengan kedua pendapat di atas, peneliti berasumsi bahwa factor internal memiliki peranan penting dalam menentukan prestasi belajar siswa yang bias didukung juga oleh factor eksternal. Terutama factor internal karena factor internal merupakan factor penentu bagi seseorang karena factor internal dikendalikan oleh individu itu sendiri. Factor internal juga saling berkaitan, untuk mendapatkan prestasi belajar yang baik, maka semua bagia dari factor internal harus baik. Sulit untuk membuat factor internal menjadi baik karena segala cobaan selalu saja dating menhampiri. Oleh karena itu, seseorang perlu mengetahui factor internalnya sendiri baik itu kekurangan maupun kelebihannya, kemudian membentuk suatu apresiasi untuk dirinya sehingga bisa mencapai hasil yang diinginkan yaitu factor internal yang baik dan prestasi belajar yang membanggakan baik untuk masa sekarang (perkuliahan) maupun masa depan (pekerjaan, rumah tangga, bermasyarakat). 
BMJ. Vol 6 No 2, 2019: 163-172

ISSN : $2615-7047$

DOI: https://doi.org/10.36376/bmj.v6i2

\section{KESIMPULAN DAN SARAN}

Dari hasil penelitian yang dilakukan, maka dapat disimpulkan bahwa:

1. Faktor Internal mahasiswa menunjukkan bahwa sebagian besar jumlah responden berada pada kategori baik.

2. Prestasi Belajar menunjukkan bahwa sebagian besar responden berada pada kategori sangat memuaskan.

3. Ada hubungan Antara Faktor Internal Mahasiswa Dengan Prestasi Belajar Berdasarkan kesimpulan dari hasil penelitian tersebut di atas, maka peneliti dapat memberikan saran-saran sebagai berikut:

1. Bagi Pengelola Institusi

Diharapkan kepada pihak institusi khususbya kepada masingmasing Pembimbing Akademik untuk lebih memperhatikan faktor internal mahasiswa karena dapat mempengaruhi prestasi belajarnya, dan hal ini dapat dilakukan dengan cara bekerjasama dengan pihak institusi agar menyediakan referensi-referensi yang berkaitan dengan faktor internal di perpustakaan. Melalui referensi-referensi tersebut mahasiswa dapat menemukan solusi yang tepat dan lebih kritis untuk menangani masalah yang berkaitan dengan dirinya sehingga walaupun ada masalah yang berkaitan dengan faktor internalnya, masalah itu tidak akan berpengaruh pada prestasi belajarnya. Disamping itu juga, pihak institusi harus merekrut dosen psikologi atau Bimbingan Konseling sehingga mahasiswa yang bermasalah dengan factor intrnalnya dapat berkonsultasi dengan dosen yang bersangkutan sehingga tidak akan mempengaruhi prestasi belajarnya. Pihak institusi sebaiknya menyarankan kepada setiap dosen agar ketika mengajar tidak hanya memperhatikan materi yang diajarkan melainkan juga memperhatikan keadaan mahasiswa yang tampak menyimpang selama perkuliahan berlangsung.

2. Bagi Mahasiswa/I Keperawatan

Diharapkan agar mahasiswa/I keperawatan lebih kritis dalam memilih dan mengambil keputusan dalam menentukan solusi yang tepat dalam menangani masalah yang berkaitan dengan faktor internalnya sehingga tidak berpengaruh pada prestasi belajarnya.

3. Bagi Peneliti

Diharapkan bahwa dengan penelitian ini akan menjadi dasar bagi peneliti untuk terus melakukan penelitian tentang factor internal dan prestasi belajar dengan tujuan untuk melihat setiap komponen faktor internal mahasiswa supaya diketahui secara pasti, apakah masing-masing komponen memberikan pengaruh yang sama atau berbeda terhadap prestasi belajar, serta melihat setiap perubahan yang terjadi sesuai dengan perkembangan ilmu pengetahuan dan teknologi. Disamping itu juga, dengan penelitian ini akan memberikan dorongan atau motivasi bagi peneliti untuk melakukan penelitian tentang materi keperawatan lainnya dan menjadi pegangan tersendiri agar peneliti dapat menerapkannya langsung.

Balimedikajurnal.com 
BMJ. Vol 6 No 2, 2019: 163-172

ISSN : $2615-7047$

DOI: https://doi.org/10.36376/bmj.v6i2

\section{DAFTAR PUSTAKA}

Dalyono, M. (2005), Psikologi Pendidikan. Jakarta: CV Infomedika.

Djaali.(2012), Psikologi Pendidikan. Jakarta: Bumi Aksara.

H, A.Aziz Alimul. (2009), Metode Pendidikan Keperawatan Teknik

AnanlisisData. Jakarta: Alemba Medika.

Setiadi. (2012), Konsep dan Praktik Penulisan Riset Keperawatan Edisi 2.

Yogyakarta: Graha Ilmu.

Subini, nini, dkk. (2012), Psikologi Pembelajaran. Yogyakarta: Mentari Pustaka.

Sumber dari internet:

Aby Farhan,(2012), Pengertian Intelegensi Prestasi

Belajarhttp://abyfarhan7.blogspot.com/2011/07/intelegensi-prestasi-

belajar-dan.html Diakses tanggal 20-09-2012

Ganis. (2010), Kualitas

Pendidikan.hhtp//garis.student.ummac.id/2010/10/26/mahalnya-biaya-

sekolah-di-masa-sekarang// Diakses tanggal 20 - 09- 2012

Haryanto,(2010), Pengertian Minat Belajar http://belajarpsikologi.com/pengertianminat/

Diakses tanggal 20-10-2012

Haryanto,(2011), Manfaat Motivasi Belajar http://belajarpsikologi.com/fungsimotivasi-dalam-proses-belajar/

Diakses tanggal 02-11-2012

Admin,(2010), Pengertian Prestasi Belajar www.psychologymania.com/2012/06/tes-prestasi-belajar.html

Diakses tanggal 07-10-2012

Wardiyati, Agustin, (2011), Faktor-Faktor Yang Mempengaruhi Prestasi Belajar.

http://id.shvoong.com/social-sciences/education/2115716-faktor-faktor-yangmempengaruhi-prestasi/

Diakses tanggal 09-03-2013

Diambil dari Jurnal:

Handari.M (2010), Hubungan Motivasi Belajar Dengan Indeks Prestasi Akademik Mahasiswa Program Studi DIII Keperawatan STIKES Wira Husada Yogyakarta.

Handayani Sri. (2008), Hubungan Pengetahuan, Sikap, Minat, dan Motivasi Belajar Dengan Prestasi Belajar Mata Kuliah Kebutuhan Dasar Manusia I Jurusan AKPER Giri Satria Husada Wonogiri. Jurnal Penelitian AKPER Giri Satria Husada Wonogiri, (1), (2). 